\title{
A theoretical consideration of the effect of preventing rumen fermentation on the efficiency of utilization of dietary energy and protein in lambs
}

\author{
BY J. L. BLACK \\ School of Agriculture, University of Melbourne, Victoria, Australia
}

(Received 23 September 1969-Accepted 27 fuly 1970)

\begin{abstract}
I. The effect of preventing rumen fermentation of feed on the utilization of energy and protein by growing lambs has been studied by theoretical means.

2. Initially, the differences in feed utilization resulting from microbial fermentation compared with digestion by host enzymes were estimated. It was assumed that a diet containing $85 \%$ of unspecified carbohydrate and $15 \%$ casein was placed directly into the rumen (ruminant lamb) or abomasum (non-ruminant lamb) of animals weighing $20 \mathrm{~kg}$, and that in both instances the diet was completely digested. In the non-ruminant lamb from 39 to $45 \%$ more net energy was available formaintenance, and from 22 to $61 \%$ more net energy was available for production, than in the ruminant lamb. The smaller differences applied to concentrate diets and the larger differences to highly fibrous diets. When dietary protein was completely degraded by microbes approximately $50 \%$ less protein was absorbed from the small intestine in the ruminant lamb than in the non-ruminant lamb. It is suggested that this may significantly reduce tissue synthesis and growth in early-weaned lambs weighing less than $30 \mathrm{~kg}$, but it may not limit growth in heavier animals.

3. Because part of the food of ruminants generally escapes fermentation and is digested by enzymes in the small intestine, and because part of the food of non-ruminants is fermented in the hind-gut, the estimates were adjusted accordingly. In this situation the utilization of digested energy in the non-ruminant lamb was from 30 to $45 \%$ more efficient for maintenance and from 10 to $60 \%$ more efficient for production than in the ruminant lamb. Some dietary proteins are so resistant to microbial degradation that a lower efficiency of utilization in the ruminant lamb when these proteins are given could only result from a limit in availability of energy.

4. Since ruminants digest crude fibre more efficiently than non-ruminants, it was calculated that the level of dietary crude fibre must exceed at least $22 \%$, and in some instances $35 \%$, of the dry matter before the ruminant digestive system results in a better utilization of dietary energy in lambs. Thus, many common feeding-stuffs would be more efficiently used by lambs if they by-passed the rumen. The possible limitations to the adoption of this procedure are discussed.

5. The present techniques available for reducing the degradation of food within the rumen are outlined. It is suggested that an improvement in food utilization in ruminants could be achieved by feeding fats or formaldehyde-treated fat-casein complexes in solid diets, or alternatively, by feeding liquid diets which activate the reticular groove.
\end{abstract}

The efficiency of feed utilization in ruminants is influenced by the activity of rumen micro-organisms. When low-protein diets are consumed, the nitrogen content of digesta increases as it passes through the rumen, with the result that more protein is absorbed from the intestine than was eaten (Hogan \& Weston, I968). Alternatively, when large quantities of soluble proteins are given there is often a substantial loss of $\mathrm{N}$ from the rumen and a reduction in protein absorption (Hogan \& Weston, I $967 b$ ). Furthermore, microbial digestion of food invariably reduces the efficiency of utilization of digested energy by animals because of the energy losses associated with methane production, heat of fermentation and poor utilization of absorbed volatile fatty acids (Blaxter, 1962 ). Hence production from ruminants is often improved when 
foods which are low in fibre and high in protein escape fermentation in the rumen and are digested by enzymes in the abomasum and small intestine. For example, wool growth of adult wethers was increased by as much as 100\% when casein was infused direct into the abomasum (Reis \& Schinckel, 1961, 1963, I964; Reis, 1969), or by $70 \%$ when orally administered casein was protected from fermentation by treatment with formaldehyde (Ferguson, Hemsley \& Reis, 1967). Chalmers, Cuthbertson \& Synge (1954) also found that pregnant ewes retained more $\mathrm{N}$ when casein was infused into the duodenum than when casein was infused into the rumen. Swanson, Thigpen, Huskey \& Hazelwood (1969) and Black (1970a) have shown that the growth rates of young ruminants are significantly increased when milk diets by-pass the rumen.

Reis (1969) has suggested that, under most grazing conditions, wool growth is limited by the amount of protein and particularly sulphur amino acids available to the wool follicle and that energy intake is relatively unimportant. Thus, the prevention of fermentation of dietary protein alone should produce marked increases in wool growth. However, with young ruminants, losses of dietary energy as well as of protein are likely to contribute to the lower growth rates. The relative importance of of these two losses for growth is unknown.

An attempt is made in this paper to assess, from theoretical considerations, the losses of energy and protein resulting from the microbial fermentation of diets in ruminants and to compare these losses with those that would be expected if the diets escaped fermentation in the rumen. The assessments are based upon the likely performances of young rather than of adult ruminants, because of the author's experience with lambs (Black, 1970 $a, b$ ) and because of the current interest in the possibility of rearing lambs to slaughter weights under intensive feeding conditions.

\section{BASIS FOR CALCULATIONS}

The calculations are made for lambs weighing $20 \mathrm{~kg}$. Initially, it is assumed that in one treatment (ruminant lamb) the entire diet is fermented within the rumen, whereas in the other treatment (non-ruminant lamb) the diet is digested by enzymes secreted into the abomasum and small intestine. This is clearly an unrealistic situation since a portion of the food eaten by ruminants generally escapes fermentation and is digested in the small intestine (Ørskov, Fraser \& Kay, 1969) and, conversely, a portion of the food consumed by simple-stomached animals is fermented by microbes in the hindgut (Hobson \& Howard, I969). However, this simplified situation enables an estimate to be made of the differences in energy and protein utilization that are likely to result from the microbial fermentation of food compared with its digestion by host enzymes. Subsequently, the calculated values are used to determine the efficiency of feed utilization for more realistic examples where some of the food is subjected to microbial action and some to host enzymes.

The ration is assumed to be completely digested by both treatments and to provide $85 \%$ of the dry matter from carbohydrate and $15 \%$ from casein. Thus, about $19 \%$ $[15 \times 5 \cdot 6 \div(15 \times 5 \cdot 6+85 \times 4 \cdot 1) \times 100]$ of the total digestible energy is derived from protein, and this has been shown (Black, $1970 b$ ) to approximate to the optimal protein 
to energy ratio required by non-ruminant lambs weighing $20 \mathrm{~kg}$. In order to avoid any possible complications arising from differences in the digestibility of various carbohydrates, or digestive upsets which may result from the consumption of an excess of any one carbohydrate (Walker \& Faichney, 1964 b), the actual carbohydrate components of the ration are not specified, but they are assumed to be composed of six carbon units. The energy content of the ration is taken to be $4.4 \mathrm{kcal} / \mathrm{g}$ dry matter (Reid, 1968).

The lambs are assumed to be given a gross energy intake equal to twice their maintenance requirement of net energy. Graham (1967) found that the maintenance requirement of lambs ranged between I00 and $104 \mathrm{kcal} / \mathrm{kg}{ }^{0.73}$ per $\mathrm{d}$. A similar value of $108 \mathrm{kcal} / \mathrm{kg}^{0.73}$ per $\mathrm{d}$ was obtained by Jagusch (1968). For the present calculations a value of $100 \mathrm{kcal} / \mathrm{kg}^{0.73}$ per $\mathrm{d}$ is used. Thus $890 \mathrm{kcal}$ is required each day for maintenance of a $20 \mathrm{~kg} \mathrm{lamb}$ and the gross energy intake of the lamb in the present calculations is $1780 \mathrm{kcal} / \mathrm{d}$. This energy is obtained from $405 \mathrm{~g}$ of dietary dry matter, which provides each lamb with $9 \cdot 6 \mathrm{~g} \mathrm{~N}$ from $6 \mathrm{I}(9 \cdot 6 \times 6.38) \mathrm{g}$ protein each day.

\section{RESULTS}

\section{Utilization of energy in ruminant and non-ruminant lambs}

The partition of energy for ruminant and non-ruminant lambs is summarized in Table I.

\section{Gross energy}

The gross energy intake is specified as $1780 \mathrm{kcal} / \mathrm{d}(7448 \mathrm{~kJ})$ for both the ruminant and non-ruminant lambs.

Table I. Theoretical utilization of dietary energy in a lamb in which the entire diet is fermented in the rumen (ruminant lamb) and in another lamb in which the diet is digested by host enzymes (non-ruminant lamb)

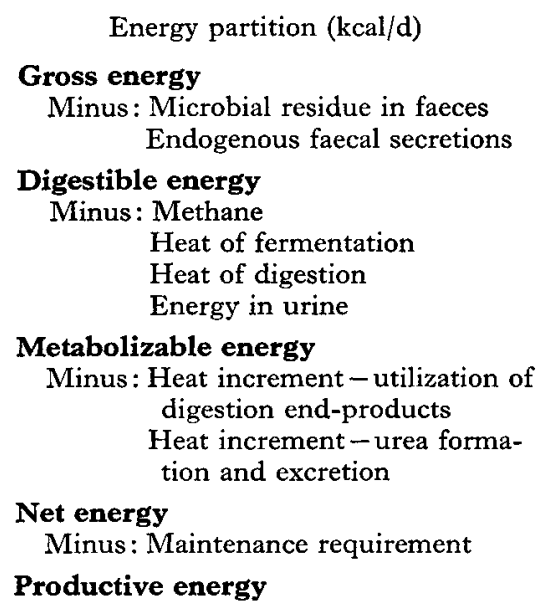

\begin{tabular}{|c|c|c|}
\hline $\begin{array}{l}\text { Ruminant } \\
\text { lamb }\end{array}$ & $\begin{array}{r}\text { Non-r } \\
\text { la }\end{array}$ & $\begin{array}{l}\text { uminant } \\
\mathrm{mb}\end{array}$ \\
\hline 1780 & & 1780 \\
\hline 18 & - & \\
\hline 27 & 27 & \\
\hline $\mathbf{7 7 3 5}$ & & $\mathbf{I 7 5 3}$ \\
\hline I74 & - & \\
\hline ro4 & $\overline{18}$ & \\
\hline 64 & $4^{I}$ & \\
\hline $\mathbf{I 3 9 3}$ & & r694 \\
\hline 276 & 229 & \\
\hline 29 & 15 & \\
\hline I088 & & 1450 \\
\hline 890 & 890 & \\
\hline I98 & & 560 \\
\hline
\end{tabular}




\section{Digestible energy}

Ruminant lamb. It is assumed that the food is completely fermented by the microorganisms within the ruminant lamb. Approximately 10\% of the fermented substrate is used for growth by the microbial population and is converted into microbial protoplasm (Hungate, 1 965). However, when this protoplasm passes from the rumen it is not completely digested by the enzymes secreted into the lower digestive tract. Experiments to determine the digestibility of rumen micro-organisms (Johnson, Hamilton, Robinson \& Garey, I944; Reed, Moir \& Underwood, I949; McNaught, Owen, Henry \& Kon, 1954) by feeding dried preparations to rats have shown that the true digestibility of bacteria ranges from 55 to $74 \%$, while that of protozoa ranges from 86 to $91 \%$. On the other hand, the recent results of Hoogenraad, Hird, White $\&$ Leng (1970) suggest that the digestibility of bacteria by sheep may be considerably higher than the results previously obtained with rats have indicated. When Bacillus subtilis and Escherichia coli, grown in a medium including ${ }^{14} \mathrm{C}$-labelled glucose, were injected into the abomasum of sheep their digestibilities were $9 \mathrm{I}$ and $85 \%$ respectively, and these increased to 94 and $92 \%$ when the bacteria were placed into the rumen.

For the present calculation the digestibility of rumen micro-organisms is assumed to be $90 \%$. Thus, approximately I $8 \mathrm{kcal}$, or I $\%$, of the gross energy consumed by the ruminant lamb appears as microbial residues in the faeces. In addition, energy from endogenous sources is also excreted in the faeces. Walker \& Cook (1967) found that the apparent digestibility of energy by milk-fed lambs receiving $20 \%$ of their energy as protein was approximately $98.5 \%$. Since the true digestibility of a similar diet has been shown by Norton (1968) to be $100 \%$, it is likely that the faecal energy was all of endogenous origin. Thus for the present calculation the faecal energy output attributable to endogenous sources is taken as $I \cdot 5 \%$ of gross energy intake or $27 \mathrm{kcal} / \mathrm{d}$. The total digestible energy available to the ruminant lamb is $1735 \mathrm{kcal} / \mathrm{d}$ [gross energy (1780) - faecal microbial residues (18) - endogenous faecal secretions (27)] or $7259 \mathrm{~kJ}$.

Non-ruminant lamb. For the non-ruminant lamb it is assumed that the diet is completely digested and absorbed in the small intestine. The only faecal energy loss is of endogenous origin which is assumed to be the same as in the ruminant lamb. The digestible energy available to the non-ruminant lamb is $1753 \mathrm{kcal} / \mathrm{d}$ [gross energy ( 1780 ) - endogenous faecal secretions (27)] or $7335 \mathrm{~kJ}$.

\section{Metabolizable energy}

In practical studies metabolizable energy is defined as digestible energy less the heat of combustion of urine and methane. However, for the present consideration it is taken to represent the energy which is available within the body of the lambs to provide the needs of maintenance and production, and is defined as above minus the heat released during digestion.

Methane:ruminant lamb. The proportion of dietary energy lost as methane during the fermentation process in ruminants depends on the relative proportions of the 
steam volatile fatty acids (VFA) formed during fermentation (Hungate, I966). These proportions are influenced by several dietary factors, including the quantity of fibre (Elliott \& Loosli, 1959) and the quantity of starch (Reid, Hogan \& Briggs, 1957) in the diet, and by the physical form of roughage (Meyer, Kromann \& Garrett, I965). The amount of methane produced from diets which are low in fibre is also related to the level of intake (Blaxter \& Clapperton, I965). At high levels of intake the rate of passage of feed through the rumen is increased, some of the feed particles escape fermentation and less methane is produced per kcal of diet ingested.

For the present calculation it is assumed that all the diet is fermented in the rumen and none passes intact to the abomasum. Blaxter \& Clapperton (1965) found that methane production in ruminants given a wide variety of diets at maintenance level of intake was related to the digestibility of the diet by the equation:

$$
C m=3.67+0.062 D
$$

where $C m$ is the methane produced in $\mathrm{kcal} / 100 \mathrm{kcal}$ gross energy and $D$ is the digestibility of the diet. If a digestibility of $97.5 \%$ is substituted in the above equation, the methane production is $9.72 \mathrm{kcal} / \mathrm{r} 00 \mathrm{kcal}$ gross energy, or almost ro kcal/roo kcal digestible energy. Therefore, methane production accounts for a loss of I74 (I735 $\times 0.10) \mathrm{kcal}$ digestible energy in the ruminant lamb.

Methane:non-ruminant lamb. Since it is assumed that there is no microbial digestion in the non-ruminant lamb, no methane is produced.

Fermentation heat:ruminant lamb. Energy evolved as heat during the depolymerization and fermentation of food in the rumen is unavailable for production in the ruminant lamb. Some of this energy may be important in reducing the expenditure of net energy for maintaining body temperature when the animals are exposed to adverse weather conditions, but for the present calculations a thermoneutral environment is assumed.

An estimate of the heat of fermentation can be obtained when the heats of combustion of the products of a fermentation reaction are subtracted from the heat of combustion of the original substrate. Calculations of this nature show that, for most dietary material, between 4 and $12 \%$ of the substrate energy is lost as heat (Blaxter, I962). Hungate ( 1966 ) estimated that the heat released when hexose is fermented to an average ratio of VFA ( 62 acetic acid: 22 propionic acid : I 6 butyric acid) is $6.5 \%$ of the initial energy. This is likely to overestimate the heat produced by about $10 \%$ because some of the energy released from the hexose is used for growth of the microbial population. Therefore, approximately $6 \%$ of the energy of the food would be released as heat during fermentation. This value is identical with that obtained by Marston (1948) when cellulose was digested in vitro by rumen micro-organisms. In the ruminant lamb $104(1735 \times 0.06) \mathrm{kcal} / \mathrm{d}$ would be lost as heat of fermentation.

Fermentation heat: non-ruminant lamb. Although the diet of the non-ruminant lamb is not fermented, a small quantity of energy is lost in the depolymerization of food during digestion. This loss represents no more than $\mathrm{I} \%$ of the digested energy (Blaxter, 1962) and therefore accounts for only $18(1752 \times 0.01) \mathrm{kcal} / \mathrm{d}$.

Energy in urine. The energy lost in urine depends upon the quantity and composition of the dry matter excreted. Several authors have established linear relationships 
between the energy content of urine and the quantity of $\mathrm{N}$ it contains (Nehring, Hoffmann, Schiemann \& Jentsch, 1963; Paladines, Reid, Van Niekerk \& Bensadoun, 1964). However, these relationships differ widely and depend upon the relative proportions of the various $\mathrm{N}$-containing compounds in urine. For example, the energy to $\mathrm{N}$ ratio of the urinary compound, hippuric acid, is $72.3 \mathrm{kcal} / \mathrm{g} \mathrm{N}$, while that of the amino acids is approximately $39 \mathrm{kcal} / \mathrm{g} \mathrm{N}$, that of creatine is $\mathrm{I} 3.3 \mathrm{kcal} / \mathrm{g} \mathrm{N}$, of allantoin $7 \cdot 4 \mathrm{kcal} / \mathrm{g} \mathrm{N}$, and of urea it is only $5 \cdot 4 \mathrm{kcal} / \mathrm{g} \mathrm{N}$.

The energy to $\mathrm{N}$ ratio of the urine of ruminants is generally higher than that of non-ruminants (Blaxter, 1962). This can be explained by the larger amounts of aromatic acids, and particularly hippuric acid, in the urine of ruminants (Martin, I969). When Blaxter \& Martin (1962) infused casein into either the rumen or the abomasum of adult sheep, the quantities of $\mathrm{N}$ excreted in the urine were similar, but the energy contents of the urine were $10 . \mathrm{I} \mathrm{kcal} / \mathrm{g} \mathrm{N}$ and $7.8 \mathrm{kcal} / \mathrm{g} \mathrm{N}$, respectively. On the other hand, Jagusch ( 1968 ) has shown for non-ruminant lambs that the energy to $\mathrm{N}$ ratio of urine decreases as the quantity of $\mathrm{N}$ excreted in the urine increases, presumably because of a higher proportion of urea which has a low energy to $\mathrm{N}$ ratio. He found that, although urine of lambs on a $5 \%$ protein diet contained $20.7 \mathrm{kcal} / \mathrm{g} \mathrm{N}$, they excreted less $\mathrm{N}$ than lambs receiving a $30 \%$ protein diet and having a urinary energy to $\mathrm{N}$ ratio of only $7.9 \mathrm{kcal} / \mathrm{g} \mathrm{N}$. Thus it appears that, when ruminant and nonruminant lambs are excreting the same quantity of urinary $\mathrm{N}$, there will be a greater loss of energy from the ruminant lamb. However, the actual energy loss from the two types of lambs will be influenced by the quantity of $\mathrm{N}$, and particularly urea, excreted in the urine. In the present example, it is likely that the ruminant lamb excretes more $\mathrm{N}$ than the non-ruminant lamb, so there may not be a great difference in the energy to $\mathrm{N}$ ratio of the urine between the two treatments. A value of $10 \mathrm{kcal} / \mathrm{g} \mathrm{N}$ is used for both treatments in the present calculation.

Energy in urine: ruminant lamb. Casein is almost completely degraded by the microorganisms in the rumen (McDonald \& Hall, I957). Most of the $\mathrm{N}$ from casein is released as ammonia and is available for incorporation into microbial cells. However, the degree of incorporation depends upon the quantity of energy available to the micro-organisms as adenosine triphosphate (ATP). Using the results obtained by Bauchop \& Elsden (1960) for the quantity of ATP required to synthesize microbial cellular material, Walker ( 1965 ) has reasoned that enough ATP is produced during the fermentation of $100 \mathrm{~g}$ carbohydrate to form $10 \mathrm{~g}$ microbial protein. In the present example, therefore, $8.5(10 \times 0.85) \mathrm{g}$ microbial protein is formed from the fermentation of $100 \mathrm{~g}$ diet. The remaining $\mathrm{I} \cdot 0 \mathrm{~g}$ ammonia-N (from the 6.5 ( $15.0-8.5$ ) $\mathrm{g}$ casein in the $100 \mathrm{~g}$ diet not converted into microbial protein) is transported to the liver where it may take part in the glutamic dehydrogenase reaction to form non-essential amino acids or it may enter the ornithine cycle of urea synthesis (Krebs, I964). The pathway followed will depend on many factors including the availability of both essential and non-essential amino acids for protein synthesis, the availability of energy (Munro, 195I) and the hormonal balance within the animal (Leathem, I964). When the quantity of non-essential amino acids is limiting protein synthesis, a considerable amount of ammonia will be converted into these acids (Snyderman, 1967). Conversely, 
when factors other than a shortage of non-essential amino acids are limiting protein synthesis, most of the ammonia will be transformed to urea and eventually excreted in the urine.

For the present consideration it is assumed that all the ammonia absorbed from the digestive tract is converted into urea. Thus of the $405 \mathrm{~g}$ diet consumed each day, $4 \cdot \mathrm{I}(\mathrm{I} \cdot 0 \times 4 \cdot 05) \mathrm{g} \mathrm{N}$ reaches the urine by this path. Almost $43 \%[(4 \cdot \mathrm{I} \div 9 \cdot 6) \times \mathrm{I} 00]$ of the dietary protein consumed by the ruminant lamb is therefore unavailable for protein synthesis. Urinary $\mathrm{N}$ is also derived from endogenous sources and from the metabolism of microbial protein absorbed from the intestine. Recalculation of the results (period 3) of Walker \& Cook (1967) shows that $0.115 \mathrm{~g} \mathrm{~N} / \mathrm{kg}$ live weight is excreted in the urine each day by lambs given a liquid diet containing $10 \%$ of the digestible energy as protein. The energy to protein ratio of the diet used by them approximates to that which is absorbed from the digestive tract of the ruminant lamb in the present calculation. For a $20 \mathrm{~kg}$ lamb this represents a urinary loss of $2 \cdot 3 \mathrm{~g} \mathrm{~N} / \mathrm{d}$.

A total of $6 \cdot 4(4 \cdot 1+2 \cdot 3) \mathrm{g} \mathrm{N}$ is excreted each day in the urine of the ruminant lamb. This amounts to a loss of $64(6 \cdot 4 \times 10) \mathrm{kcal}$ digestible energy.

The metabolizable energy available to the ruminant lamb is thus $1393 \mathrm{kcal} / \mathrm{d}$ [digestible energy (1735) - methane energy (174)-fermentation heat (104)-urinary energy (64)] or $5828 \mathrm{~kJ}$.

Energy in urine: non-ruminant lamb. In the non-ruminant lamb all the amino acids released during the digestion of casein are absorbed from the small intestine. Further recalculation of the results (period 3) presented by Walker \& Cook (1967) for lambs given a liquid diet in which $20 \%$ of the digestible energy was protein shows that $0.204 \mathrm{~g} \mathrm{~N} / \mathrm{kg}$ live weight was excreted in urine per d. For a $20 \mathrm{~kg}$ lamb this represents a urinary loss of $4^{\cdot} \mathrm{I} g \mathrm{~N} / \mathrm{d}$. The non-ruminant lamb, therefore, loses $4^{\mathrm{I}}\left(4^{\cdot} \mathrm{I} \times \mathrm{IO}\right)$ $\mathrm{kcal} / \mathrm{d}$ in its urine.

The metabolizable energy available to the non-ruminant lamb is then $1694 \mathrm{kcal} / \mathrm{d}$ [digestible energy (I753)-digestion heat (I8) - urinary energy (4I)] or $7088 \mathrm{~kJ}$.

\section{Net energy}

A proportion of metabolizable energy is lost as heat during the metabolism of absorbed nutrients. The magnitude of the loss is influenced by many factors, including the plane of nutrition of the animal, the balance of dietary nutrients, the productive function of the absorbed nutrients, the end-products of digestion, the environmental temperature and the age of the animal (Blaxter, 1962).

The heat increment is lowest when absorbed nutrients are used for body maintenance and highest when they are used for fat deposition. The results of Blaxter, Clapperton \& Wainman (1966) suggest that the heat increment for growth is similar to that for fat deposition, since they found that the efficiency of utilization of metabolizable energy in young ruminant calves was not greatly different from that in fattening cattle. For the present calculation heat increments measured in fattening animals are used when estimates for growth are required.

Heat increment from end-products of digestion: ruminant lamb. VFA are the main endproducts of digestion in the ruminant lamb. Marston (1948) found that $76 \%$ of the 
energy of cellulose digested in vitro appears as VFA. The quantity of heat released during the utilization of VFA depends upon the relative proportions of the various acids absorbed and the productive function for which they are used (Blaxter, 1962). When a mixture of VFA ( 90 acetic, 6 propionic and 4 butyric) was given to fasting sheep, Armstrong, Blaxter \& Graham (1957) found that $15 \%$ of the energy of the VFA was lost as heat. On the other hand, when VFA are used for fattening, the heat loss is primarily dependent upon the quantity of acetic acid absorbed from the digestive tract (Blaxter, 1962). For the present calculations the heat loss of $42 \%$ recorded by Armstrong, Blaxter, Graham \& Wainman (1958), for fattening sheep in which the proportions of VFA in the rumen were 54 acetic: 30 propionic: $16 \mathrm{n}$-butyric, is used.

It is assumed that during the fermentation of carbohydrates $10 \%$ of the energy appears as microbial protoplasm, $10 \%$ as methane and $6 \%$ as heat of fermentation, and the remaining $74 \%$ is absorbed as VFA. Since the energy in carbohydrates represents $81 \%$ (casein $15 \times 5^{.6} \mathrm{kcal} / \mathrm{g}$ and carbohydrates $85 \times 4^{\cdot 1} \mathrm{kcal} / \mathrm{g}$ ) of the total energy of the diet, $1067(1780 \times 0.8 \mathrm{I} \times 0.74) \mathrm{kcal}$ of the metabolizable energy derived from carbohydrate is in the form of VFA. In addition, el-Shazly (1952) showed that the fermentation of casein hydrolysate by rumen micro-organisms in vitro led to the production of equimolar proportions of ammonia, carbon dioxide and VFA. From the known heats of combustion of various amino acids and their relative percentages in casein, it can be calculated that about $40 \%$ of the energy of casein was converted into VFA. Therefore, another $135(1780 \times 0.19 \times 0.40) \mathrm{kcal}$ metabolizable energy is in VFA. This means that VFA contributes $1202\left(\mathrm{I}_{0} 67+\mathrm{r} 35\right) \mathrm{kcal}$ to the total metabolizable energy available to the ruminant lamb. The remaining I9I (1393- I202) kcal would be mainly in microbial protoplasm.

The maintenance requirement of the ruminant lamb has already been assumed to be $890 \mathrm{kcal}$ net energy/d. If the energy for maintenance is derived from VFA with an efficiency of $85 \%$ (see Armstrong et al. 1957), 1047 [890 $\times(100 \div 85)]$ kcal of metabolizable energy is used for maintenance. The heat increment associated with maintenance is therefore $\mathrm{I}_{57}(1047 \times 0.15) \mathrm{kcal} / \mathrm{d}$. The remaining ${ }_{155}(\mathrm{I} 202-1047) \mathrm{kcal}$ of metabolizable energy in VFA is used for production with an efficiency of $58 \%$ (see Armstrong et al. 1958). Hence, an additional $65\left(\mathrm{r}_{55} \times 0.42\right) \mathrm{kcal}$ is lost as heat. During the utilization of VFA by the ruminant lamb $222\left(\mathrm{r}_{57}+65\right) \mathrm{kcal}$ is lost as heat.

Further heat is lost during the utilization of the metabolizable energy derived from microbial protoplasm. It is assumed that the microbes are digested in the intestine and not fermented and that the energy released is used only for production. The efficiency with which this energy is used will therefore be comparable to the values obtained for fattening non-ruminants. Armstrong, Blaxter \& Graham (1960) showed that the efficiency of utilization of glucose for lipogenesis in sheep was $7 \mathrm{r} \cdot 5 \%$ when it was infused into the abomasum. When this value is used $54(\mathrm{I} 9 \mathrm{I} \times 0.285) \mathrm{kcal}$ heat are evolved during the utilization of the metabolizable energy originating from microbial protoplasm. The ruminant lamb therefore loses $276(222+54) \mathrm{kcal}$ as heat during the utilization of the end-products of digestion.

Heat increment of end-products of digestion: non-ruminant lamb. In the non-ruminant 
lamb carbohydrate is completely digested to simple sugars. Since glucose infused into the abomasum of fasting sheep does not lead to an increase in heat production (Blaxter, 1962), no energy is lost during the utilization of glucose for maintenance by the non-ruminant lamb. However, the remaining $804(\mathrm{r} 694-890) \mathrm{kcal}$ metabolizable energy are used for production with an efficiency of $71 \cdot 5 \%$ (Armstrong $e$ t al. 1960). Therefore, $229(804 \times 0.285) \mathrm{kcal}$ are lost as heat during the utilization of the endproducts of digestion by the non-ruminant lamb.

Heat increment from the formation and excretion of urea. Martin \& Blaxter (1965) estimated that the conversion of ammonia into urea and its subsequent excretion requires $5 \cdot 2 \mathrm{kcal} / \mathrm{g} \mathrm{N}$.

Heat increment from urea: ruminant lamb. It has already been estimated that $4^{\cdot} \cdot \mathrm{g}$ of urea-N appear in the urine as a direct result of casein fermentation. Added to this is the urea that is likely to be excreted following the digestion of the material passing from the rumen. Recalculation of the results for period 3 of Walker \& Cook (1967) shows that approximately $0.075 \mathrm{~g}$ urea- $\mathrm{N} / \mathrm{kg}$ live weight is excreted each day by lambs receiving a liquid diet containing $10 \%$ of the digestible energy as protein. For a $20 \mathrm{~kg}$ lamb this is $\mathrm{I} \cdot 5 \mathrm{~g}$ urea- $\mathrm{N} / \mathrm{d}$. A total of $5.6 \mathrm{~g}$ urea-N is excreted by the ruminant lamb per $\mathrm{d}$ and this has an energy cost of $29(5 \cdot 6 \times 5 \cdot 2) \mathrm{kcal}$.

The total quantity of metabolizable energy lost as heat in the ruminant lamb is thus $305(276+29) \mathrm{kcal} / \mathrm{d}$. A similar value for the total loss of metabolizable energy as heat can be obtained from the method suggested by the Agricultural Research Council (1965) report. Here the efficiency of energy utilization for maintenance $(\mathrm{km})$ and for fattening $(k f)$ are calculated from the equations, $k m=0.30 Q+54.6$ and $k f=$ $0.8 \mathrm{I} Q+3$, where $Q$ is the metabolizable energy expressed as a percentage of the gross energy of the diet. In the present calculation $Q=78, k m=7^{8}$ and $k f=66$. The metabolizable energy required for maintenance is I I $4 \mathrm{I}[890 \times(\mathrm{IOO} \div 78)] \mathrm{kcal}$ with 25I (II4I-890) kcal being released as heat. The metabolizable energy available for production is therefore 252 ( $1393-114 \mathrm{I}) \mathrm{kcal}$. The heat increment associated with production is $86(252 \times 0.34) \mathrm{kcal}$, giving a total heat loss of $337(25 \mathrm{I}+86) \mathrm{kcal} / \mathrm{d}$. The net energy available to the ruminant lamb is $1088 \mathrm{kcal} / \mathrm{d}$ [metabolizable energy ( 1393 ) - heat increment associated with utilization of digestion end-products, (I) VFA (maintenance, 157 ; production, 65 ), (2) microbial protoplasm (production, 54) - heat increment from urea formation and excretion (29)] or $455^{2} \mathrm{~kJ}$.

Heat increment from urea: non-ruminant lamb. With lambs given a liquid diet in which $20 \%$ of the energy was supplied from protein, the results of Walker \& Cook ( 1967$)$ (period 3) show that $0.147 \mathrm{~g}$ urea- $\mathrm{N}$ was excreted per $\mathrm{kg}$ live weight per $\mathrm{d}$. For the $20 \mathrm{~kg}$ non-ruminant lamb in the present calculation, $2.9 \mathrm{~g}$ urea-N would be expected to be excreted each day. The formation and excretion of $2.9 \mathrm{~g}$ urea-N have an energy cost of $15(2 \cdot 9 \times 5 \cdot 2) \mathrm{kcal} / \mathrm{d}$.

The net energy available to the non-ruminant lamb is $1450 \mathrm{kcal} / \mathrm{d}$ [metabolizable energy (1694) - heat increment associated with utilization of digestion end-product (maintenance, 0 ; production, 229) - heat increment from urea formation and excretion (I5)] or $6067 \mathrm{~kJ}$. 


\section{Productive energy}

Productive energy is that energy remaining after the maintenance requirement has been subtracted. It is assumed that $890 \mathrm{kcal}$ is required for the maintenance of a $20 \mathrm{~kg}$ lamb.

Ruminant lamb. The quantity of dietary energy available for productive purposes in the ruminant lamb is therefore $198 \mathrm{kcal} / \mathrm{d}$ [net energy (1088)-maintenance requirement $(890)$ ] or $828 \mathrm{~kJ}$.

Non-ruminant lamb. The quantity of dietary energy which can be used for production in the non-ruminant lamb is $560 \mathrm{kcal} / \mathrm{d}$ [net energy ( $\left.145^{\circ}\right)$-maintenance requirement $(890)]$ or $2343 \mathrm{~kJ}$.

Table 2. Theoretical utilization of dietary protein in a lamb in which the entire diet is fermented in the rumen (ruminant lamb) and in another in which the diet is digested by host enzymes (non-ruminant lamb)

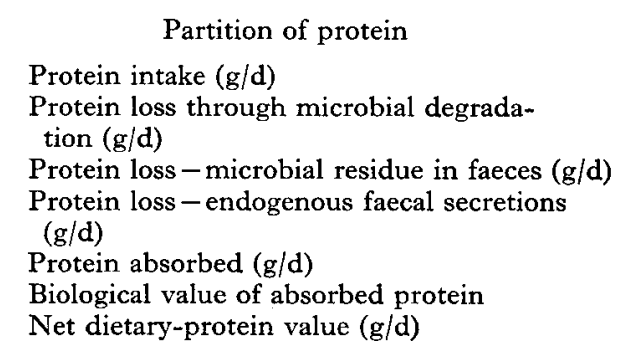

$\begin{array}{cc}\begin{array}{c}\text { Ruminant } \\ \text { lamb }\end{array} & \begin{array}{c}\text { Non-ruminant } \\ \text { lamb }\end{array} \\ 6 \mathrm{I} \cdot 0 & 6 \mathrm{I} \cdot 0 \\ 26.6 & - \\ 3.4 & - \\ 0.5 & 4 \cdot 2 \\ 30.5 & 56 \cdot 8 \\ 0.80 & 0.80 \\ 24.3 & 45.4\end{array}$

Utilization of protein by ruminant and non-ruminant lambs

At high levels of protein intake fermentation can result in a loss of $\mathrm{N}$ from the rumen and a change in the amino acid pattern of the original protein to that of microbial protein. An estimate of the net value of dietary protein for the ruminant and the nonruminant lamb is given in Table 2.

\section{Loss of dietary protein during fermentation}

Ruminant lamb. On the theoretical grounds proposed by Walker (1965), it is assumed that sufficient ATP is released from the fermentation of $100 \mathrm{~g}$ of the diet to convert $8.5 \mathrm{~g}$ of dietary protein into microbial protein. Thus, $34.4(8.5 \times 4 \cdot 05) \mathrm{g}$ of the total $6 \mathrm{I} g$ protein consumed each day would be available as microbial protein for digestion by the host. It is assumed that the $\mathrm{N}$ from the remaining $26.6 \mathrm{~g}$ protein is excreted as urea in the urine. Moreover, microbial protein is not completely digested. Hoogenraad et al. (1970) showed that the digestibility of labelled bacteria which were injected into either the abomasum or the rumen of sheep ranged from 85 to $94 \%$. The values are in close agreement with the estimated true digestibility of $86 \%$ for casein given to sheep by Ellis, Garner, Muhrer \& Pfander (1956). For the present calculation, the digestibility of rumen micro-organisms is assumed to be $90 \%$; hence $3 \mathrm{I} \cdot 0\left(34^{\circ} \times\right.$ $0.90) \mathrm{g}$ microbial protein are absorbed from the intestine and $3.4\left(34^{\circ} 4-3 \mathrm{I}^{\circ} \mathrm{O}\right) \mathrm{g}$ are excreted in the faeces of the ruminant lamb each day.

In addition, the faeces contain $\mathrm{N}$ which is derived from intestinal secretions and 
mucosal cells (Loesche, I968). Hogan \&. Weston (r968) have recently estimated that the intestines of sheep contribute $0.18 \mathrm{~g} \mathrm{~N} / 100 \mathrm{~g}$ organic matter passing from the abomasum to the total secretion of metabolic faecal nitrogen (MFN). This value is used for the ruminant lamb in the present calculation. Since ro $\%$ of the dietary intake of the ruminant lamb has been considered previously to be converted into microbial protoplasm, the quantity of organic matter leaving the abomasum is approximately $40.5(405 \times 0.10) \mathrm{g} / \mathrm{d}$. Thus $0.073(0.405 \times 0.18) \mathrm{g} \mathrm{N}$ or $0.5(0.073 \times$ 6.25) $\mathrm{g}$ protein which is excreted in the faeces is derived from the intestine. A total of $3.9(3.4+0.5) \mathrm{g}$ protein is excreted in the faeces and $30.5(34.4-3.9) \mathrm{g}$ protein are apparently absorbed from the intestine of the ruminant lamb each day.

Non-ruminant lamb. Casein placed direct into the abomasum of sheep is completely digested and absorbed (Reed et al. 1949; Blaxter \& Martin, 1962). The N excreted in the faeces will therefore be entirely from endogenous sources. The MFN excretion of non-ruminants ranges from about 0.1 to $0.2 \mathrm{~g} \mathrm{~N} / \mathrm{I} 00 \mathrm{~g}$ dry-matter intake (Hogan \& Weston, I968). Walker \& Faichney (1964a) have recorded a value of $0.29 \mathrm{~g} \mathrm{~N} / \mathrm{ro0} \mathrm{g}$ dry-matter intake. However, this value is probably too high, since it was obtained from an experiment in which the lambs received a protein-free diet which proved to be relatively indigestible, and subsequently Walker \& Cook (1967) have shown that MFN excretion is strongly related to faecal dry-matter output. For the present calculations, the value of $0.165 \mathrm{~g} \mathrm{~N} / 100 \mathrm{~g}$ dry-matter intake, which was obtained by Walker \& Cook ( 1967$)$ for a well-digested diet, is preferred. This means that $0.67(4.05 \times 0.165) \mathrm{g}$ of $\mathrm{N}$ or $4.2(0.67 \times 6.25) \mathrm{g}$ of protein are excreted in the faeces of the non-ruminant lamb daily and $56 \cdot 8(6 \mathrm{I} \cdot 0-4 \cdot 2) \mathrm{g}$ of protein are apparently digested.

\section{Biological value (Bv) of absorbed protein}

Although the amino acid composition of the microbial protein absorbed by the ruminant lamb is different from that of casein, Reed et al. (1949) showed that the BVs of both were similar (about 0.80 ).

\section{Net dietary-protein value (ND-pv)}

ND-pv (Platt \& Miller, 1959) is a useful means of showing differences in the efficiency of utilization of dietary protein by the ruminant and the non-ruminant lamb.

ND-pv is defined as the product of the crude protein (CP) content of a diet and its net protein utilization (NPU), i.e.

$$
\mathrm{NDpv}=\mathrm{CP} \times \mathrm{NPU} .
$$

NPU is described (Bender \& Miller, 1953) as the product of protein digestibility $(D)$ and Bv. So,

where

$$
\mathrm{NPU}=D \times \mathrm{BV},
$$

$$
D=\text { absorbed } \mathrm{N} \div \text { intake } \mathrm{N} \text {. }
$$

However, digestibility described in this way is not always a true indication of the protein absorbed by a ruminant. The digestibility of casein in the rumen is high, but 
much of the $\mathrm{N}$ passes from the rumen in the form of ammonia and cannot be used by the animal for protein synthesis. For the present calculations, therefore,

$$
D=\text { absorbed protein (amino acid) } \mathrm{N} \div \text { intake } \mathrm{N} \text {. }
$$

Thus, a direct comparison can be made between the ruminant and the non-ruminant lamb in a way for which NPU was originally designed.

Ruminant lamb. The ND-pv for the ruminant lamb is $6 \cdot 0[\{\mathrm{I} 5 \times(30 \cdot 5 \div 6 \mathrm{I})\} \times 0 \cdot 80] \mathrm{g} /$ Ioo $\mathrm{g}$ diet or $24.3 \mathrm{~g}$ protein/d.

Non-ruminant lamb. The ND-pv for the non-ruminant lamb is $\mathrm{II} \cdot 2[\{\mathrm{I} 5 \times(56 \cdot 8 \div 6 \cdot \mathrm{I})\}$ $\times 0.80] \mathrm{g} / \mathrm{IOO} \mathrm{g}$ diet or $45.4 \mathrm{~g}$ protein $/ \mathrm{d}$. In the present example the fermentation of dietary protein results in only $54 \%$ of the utilizable protein of the non-ruminant lamb being available to the ruminant lamb.

\section{DISCUSSION}

The preceding calculations show that the quantity of dietary energy and protein available to the ruminant lamb is considerably less than that available to the nonruminant lamb. The efficiency of utilization of truly digested energy was estimated to be $6 \mathrm{I} \%$ by the ruminant lamb and $83 \%$ by the non-ruminant lamb. The net energy obtained from the diet by the ruminant lamb was $75 \%$ of that obtained by the non-ruminant, while the energy available to the ruminant lamb for use in productive functions was only about one-third of that available to the non-ruminant lamb.

The above values apply only to the level of energy intake stipulated for the particular calculations. In general, they depend upon the relative proportions of the metabolizable energy used for maintenance and for production, and in ruminants, they also depend upon the quantity of acetic acid produced during digestion (Blaxter, I962). In Table 3 the likely ranges in the efficiency of utilization of truly digested energy by the ruminant and non-ruminant lambs are shown for both maintenance and production. For high-fibre diets in which it is assumed that the metabolizable energy represents only $36 \%$ of the gross energy of the diet, the efficiency of utilization of digested energy by the ruminant lamb is about $52 \%$ for maintenance and $26 \%$ for production. Conversely, with low-fibre diets where acetic acid production is low and the metabolizable energy of the diet is taken to represent $77 \%$ of gross energy, the efficiencies of utilization of digested energy are $61 \%$ and $52 \%$, respectively, for maintenance and for production. The corresponding values for the non-ruminant lamb are $95 \%$ for maintenance and $67 \%$ for production. Thus the energy available to a non-ruminant lamb is approximately $39-45 \%$ higher for maintenance and approximately $22-6 \mathrm{I} \%$ higher for production than that energy available to a ruminant lamb.

The fermentation of dietary protein by micro-organisms in the digestive tract often results in a loss of protein and an alteration to the amino acid pattern of the protein absorbed from the small intestine (McDonald, 1968). Consequently, the amount of protein which was absorbed and available for tissue synthesis by the ruminant lamb in the present example was only $54 \%$ of that which could be utilized by the nonruminant lamb. It is possible that the difference between the two treatments should 
even be a little greater. The MFN excretion by the ruminant lamb was calculated to be only $0.15[(3 \cdot 9 \div 6 \cdot 25) \div 4.05] \mathrm{g} \mathrm{N} / \mathrm{r} 00 \mathrm{~g}$ dry-matter intake, whereas the value for ruminants commonly falls between 0.40 and $0.55 \mathrm{~g} \mathrm{~N} / 100 \mathrm{~g}$ dry-matter intake (Agricultural Research Council, 1965). The discrepancy probably arises because the entire diet was assumed to be digested, but normally the diets of ruminants are relatively indigestible and result in a large output of faecal dry matter which has been closely related to MFN excretion (Hutchinson, 1958).

Table 3. Utilization of truly digested energy for maintenance and production by ruminant and non-ruminant lambs

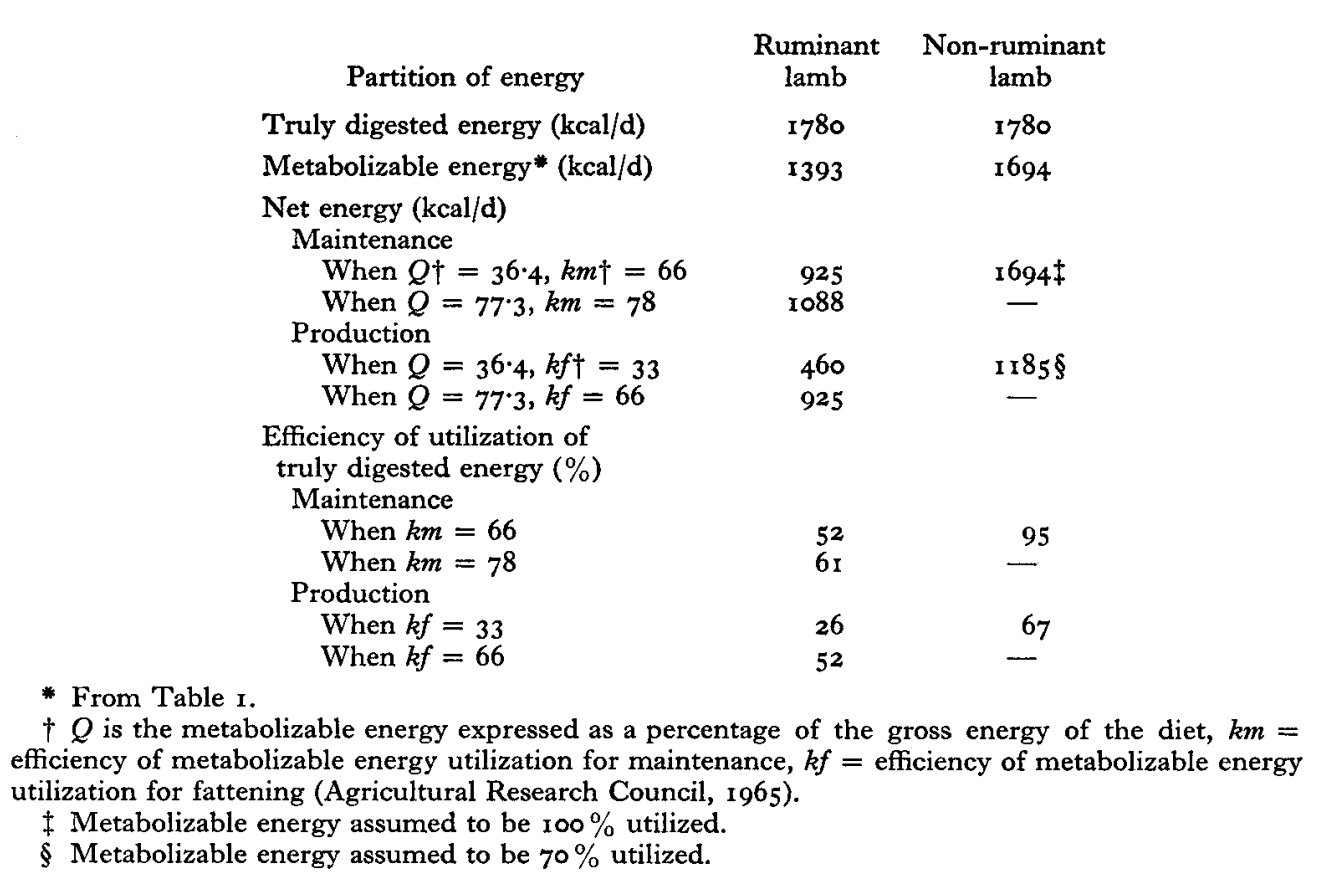

Although there is a marked difference in the quantity of protein absorbed by the two treatments, the difference in the amount of protein which is utilized or retained in tissues largely depends upon the physiological state of an animal and its capacity to synthesize tissue proteins. Since the protein intake relative to energy intake of the lambs in the present example approximated to the requirement of a $20 \mathrm{~kg}$ lamb (Black, I $970 \mathrm{~b}$ ), most of the protein absorbed could be used for tissue synthesis, the limiting factors being the amino acid pattern of the protein and the availability of energy. In other instances, the physiological state of animals may be such that no advantage is obtained when protein is digested by mammalian enzymes. For example, Blaxter $\&$ Martin ( 1962 ) found that, when casein was infused into either the abomasum or the rumen of adult sheep, the percentage of the added $\mathrm{N}$ excreted in the urine was similar with both treatments. Although more amino acids were undoubtedly absorbed in the abomasal infusion treatment, they were presumably not used for tissue synthesis since the $\mathrm{N}$ was subsequently excreted in the urine. 
Black $(1970 b)$ has recently shown that the protein requirements (expressed in terms of digested calories from protein as a percentage of the total digested calories) of non-ruminant lambs fall from 26.5 to $12.0 \%$ as live weight increases from 8 to $30 \mathrm{~kg}$. For the ruminant lamb in this theoretical calculation, the amount of protein absorbed and available for synthetic purposes represented approximately $12 \%$ $\left[\left\{\left(23^{\cdot} \cdot 1 \times 5^{\cdot} \cdot 6\right) \div 1088\right\} \times 100\right]$ of the net energy intake. Thus, for growing lambs weighing more than about $30 \mathrm{~kg}$ the loss of dietary protein resulting from microbial fermentation is not likely to substantially restrict growth rate. On the other hand, with earlyweaned lambs weighing less than $30 \mathrm{~kg}$, protein loss could be an important factor limiting production.

The theoretical calculations have illustrated the likely differences in the efficiency of energy and protein utilization resulting from either the microbial fermentation of food or its digestion by host enzymes in lambs. However, in reality, these values need to be modified since a part of the diet of ruminants escapes fermentation and is digested in the small intestine, while part of the diet of non-ruminants is fermented in the hind-gut.

Table 4. Estimates of the percentage of different nutrients digested in the intestine of sheep

\begin{tabular}{|c|c|c|c|c|}
\hline \multirow[t]{2}{*}{ Authority } & \multirow[t]{2}{*}{ Diet } & \multirow[t]{2}{*}{ Nutrient } & \multicolumn{2}{|c|}{$\begin{array}{l}\text { Digestion in intestine } \\
(\% \text { of total digested })\end{array}$} \\
\hline & & & $\begin{array}{l}\text { Small } \\
\text { + large }\end{array}$ & Small \\
\hline \multirow[t]{3}{*}{ Bruce et al. (1 966$)$} & Hay & $\begin{array}{l}\text { Organic matter } \\
\text { Cellulose }\end{array}$ & $\begin{array}{r}27 \\
6\end{array}$ & $\begin{array}{r}16 \\
-I\end{array}$ \\
\hline & Hay, maize & $\begin{array}{l}\text { Organic matter } \\
\text { Cellulose }\end{array}$ & $\begin{array}{r}32 \\
8\end{array}$ & $\begin{array}{r}8 \\
-6\end{array}$ \\
\hline & $\begin{array}{l}\text { Hay, soya- } \\
\text { protein }\end{array}$ & $\begin{array}{l}\text { Organic matter } \\
\text { Cellulose }\end{array}$ & $\begin{array}{r}35 \\
9\end{array}$ & $\begin{array}{r}25 \\
-2\end{array}$ \\
\hline \multirow[t]{5}{*}{ Hogan \& Weston (1967a) } & Wheaten hay & $\begin{array}{l}\text { Organic matter } \\
\text { Nitrogen }\end{array}$ & $\begin{array}{r}33 \\
272\end{array}$ & - \\
\hline & & Cellulose & 30 & - \\
\hline & Lucerne hay & Organic matter & 35 & - \\
\hline & & Nitrogen & 24 & - \\
\hline & & Cellulose & 10 & - \\
\hline \multirow[t]{4}{*}{ Topps et al. (1968) } & Concentrate & Dry matter & 21 & 17 \\
\hline & & Energy & 28 & 23 \\
\hline & Hay & Dry matter & 33 & 22 \\
\hline & & Energy & I9 & 7 \\
\hline \multirow[t]{2}{*}{ Tucker et al. (I968) } & Concentrate & Starch & Io & - \\
\hline & $\begin{array}{l}(63.5 \% \\
\text { starch })\end{array}$ & Starch & 18 & - \\
\hline \multirow[t]{4}{*}{ Ørskov et al. (1969) } & $\begin{array}{l}\text { Barley } \\
\text { (restricted) }\end{array}$ & Starch & 4 & 3 \\
\hline & $\begin{array}{l}\text { Barley } \\
\text { (ad. lib.) }\end{array}$ & Starch & 7 & 5 \\
\hline & Barley, grass & Starch & 13 & 8 \\
\hline & $\begin{array}{l}\text { Ground } \\
\text { maize }\end{array}$ & Starch & 15 & - \\
\hline \multirow[t]{2}{*}{ Vidal et al. (1969) } & Hay & Starch & $\mathbf{I}$ & I \\
\hline & $\begin{array}{l}25 \% \text { hay, } \\
75 \% \text { grain }\end{array}$ & Starch & 12 & I I \\
\hline
\end{tabular}


The quantity of food escaping fermentation in ruminants depends upon the level of food intake ('Tucker, Mitchell \& Little, I968), the nature of the dietary carbohydrate (Baker, Nasr, Morrice \& Bruce, 1950; Ørskov et al. 1969), and the percentage of fibre in the diet (Hogan \& Weston, I967a). Several estimates of the percentage of different nutrients that escape fermentation and are digested in the intestines of sheep are shown in Table 4 . As much as $35 \%$ of the total digestion of organic matter may occur in the intestines (Hogan \& Weston, $1967 a$ ), but some of the organic matter digested will be microbial protoplasm (which was accounted for in the theoretical calculations) and some will be fermented by micro-organisms in the large intestine (Bruce, Goodall, Kay, Phillipson \& Vowles, I966). The results of Bruce et al. (I966) suggest that the entire intestinal digestion of cellulose occurs in the hind-gut and, although Marshall (1949) found that approximately $15 \%$ of pentosan digestion occurred in the small intestine, it is probable that little crude fibre is digested by host enzymes. The dietary organic material which is mainly digested in the small intestine is starch and protein. Sugars are almost completely fermented by micro-organisms in the rumen (Armstrong, 1965). Recalculation of the results of Vidal, Hogue, Elliot \& Walker (I969) show that, when concentrate diets were given to sheep, i I \% of the total starch digestion occurred in the small intestine. Tucker et al. (1968) have recorded $18 \%$ of starch digestion in the entire intestines of sheep. The amount absorbed from the small intestine depends upon the nature of the starch (Baker et al. 1950), but complete digestion of maize starch in the small intestine of sheep has been reported (Wright, Grainger \& Marco, I966).

It would seem that when ruminants are eating roughages only a small quantity of dietary energy is digested in the small intestine (Vidal et al. I969). Conversely, when diets of concentrate or concentrate and hay are given $a d l i b$. perhaps $20 \%$ of the dietary energy is digested in the small intestine. Hence, if $20 \%$ of the energy digested by the ruminant lamb in the theoretical calculation were digested in the small intestine, approximately II6I $[(\mathrm{I} 780 \times 0.83 \times 0.20)+(\mathrm{I} 780 \times 0.6 \mathrm{I} \times 0.80)] \mathrm{kcal}$ of net energy would be released, giving an efficiency of digested energy utilization' of $65 \%$ $[(1 \mathrm{r} 6 \mathrm{I} \div \mathrm{I} 780) \times 100]$.

The theoretical efficiency of protein utilization by the ruminant lamb was also calculated for a specialized situation in which all the dietary protein was digested by the rumen micro-organisms. This situation is approximated to only when highly soluble proteins or non-protein nitrogenous substances such as urea are fed. A portion of most dietary protein passes intact to the intestine (Smith, I969). Some proteins, such as those from fish meal (Conrad, Miles \& Butdorf, 1967), zein (Ely, Little, Woolfolk \& Mitchell, 1967) and forage oats (Hogan \& Weston, 1969) can be given at high levels with little loss of $\mathrm{N}$ during passage of digesta through the rumen. With proteins of this type, the utilization of $\mathrm{N}$ is similar to that in non-ruminants, being dependent upon the digestibility and amino acid pattern of the protein, and the availability of energy for protein synthesis.

There are few quantitative estimates of the dietary material fermented by microorganisms in non-ruminants. With omnivorous and carnivorous animals, fermentation is probably not of major importance (Hobson \& Howard, I969). Hedin (1962) 
measured the volume of gas produced in the stomach and intestines of rats fed on a variety of dehydrated human foods and found that between 2 and $8 \mathrm{ml}$ of gas were recovered after the consumption of ro $g$ diet. These volumes would be obtained from the fermentation of only 0.1 to $0.4 \%$ of the total diet. Blair, Dern \& Bates (r947) have suggested that, because of absorption of gas from the intestine, the actual gas production in man may be ten to twenty-five times greater than that measured by rectal collection. Hence, in Hedin's rats, $2 \cdot 5-10 \%$ of the diets may have been fermented by microbes. Similar values for man can be calculated from the results of Blair et al. (1947) and Askevold (1956).

Alternatively, in some non-ruminants a considerable amount of dietary material is digested in the hind-gut. For example, the digestibility of acid-detergent fibre, which presumably occurs mostly in the hind-gut, has been reported to be $38 \%$ in horses (Fonnesbeck, 1969 ), $33-39 \%$ in pigs and $\mathrm{I}-\mathrm{I} 3 \%$ in rats (Keys, Van Soest \& Young, I969). Similarly, when lucerne was placed direct into the abomasum of young calves $29 \%$ of the crude fibre was digested (Putnam \& Davis, 1965), and when a purified wood cellulose slurry was infused into the caecum of sheep $33 \%$ of the cellulose was digested (Warner, Mitchell \& Little, 1968). Starch may also be fermented in the large intestine of non-ruminants, but the amount depends upon the nature and method of preparation of the starch. Although quantitative values were not presented, Baker et al. (1950) showed that a large part of the digestion of raw potato starch in rats, mice, rabbits, guinea-pigs and pigs occurred in the large intestine, whereas maize starch was almost completely digested in the small intestine. The digestion of potato starch in the small intestine was improved by both cooking and grinding. The reported digestibility of starches in the small intestines of ruminants is variable, but is generally low (Ørskov \& Fraser, 1968; Huber, 1969). This has been related to the low activity of the starch-digesting enzymes, amylase and maltase, found in lambs (Walker, 1959) and calves (Huber, Jacobson, Allen \& Hartman, I961). On the contrary, Wright et al. (1966) found that maize starch is almost completely digested by host enzymes. There is some indication that increasing the starch content in diets of sheep results in an increased activity in pancreatic amylase (Clary, Mitchell \& Little, 1967).

Kirk (1949) reported that flatus egestion in human subjects given either $50 \mathrm{~g}$ lactose or I 1 milk daily did not differ from normal, and similarly, Hedin \& Adachi (1962) reported low levels of gas production in the intestines of rats given a diet containing I $8 \%$ casein. Lactose digestion in the young calf is almost complete (Huber, 1969), and, although the lactase activity of the small intestine of some mammals has been reported to decrease with age (De Groot \& Hoogendoorn, 1956), it appears that lactase production in the intestinal mucosa of calves responds greatly to high-lactose diets (Huber, Rifkin \& Keith, 1964; Huber, Natrajan \& Polan, 1967). The digestibility of casein infused into the abomasum of adult sheep is also very high (Blaxter $\&$ Martin, I962). Thus, when ruminants receive milk diets which pass intact to the abomasum, the amount of diet fermented in the hind-gut is probably extremely small. Therefore, the energy and protein economy of ruminants on milk diets should be similar to the values calculated for the non-ruminant lamb. On the other hand, less energy would be available to the non-ruminant lamb when some starches and fibrous 
materials are given. The maximum quantity of dietary energy digested in the hind-gut is difficult to assess, but $30 \%$ may be a realistic estimate. If so, $\mathrm{I} 348$ [( $1780 \times 0.82 \times$ $0.70)+(1780 \times 0.61 \times 0.30)] \mathrm{kcal}$ would be the minimum amount of net energy available to the non-ruminant lamb considered in this paper.

It seems that the efficiency of utilization of digested energy by non-ruminant lambs is invariably superior to that of ruminant lambs. From a combination of the estimated range in the percentages of energy digested by micro-organisms and by host enzymes for both ruminants and non-ruminants, and the values presented in Table 3, which allows for the composition of the VFA absorbed, it can be estimated that energy utilization is likely to be from 30 to $45 \%$ more efficient for maintenance and from to to $60 \%$ more efficient for production in non-ruminant lambs than in ruminant lambs.

Since digested energy is used more efficiently in the non-ruminant lamb, production from ruminants should be improved when highly digestible diets by-pass the rumen. However, ruminants digest fibrous diets more efficiently than do non-ruminants. Thus a level of dietary fibre must exist at which the efficiency of energy utilization is the same whether the diet is consumed per os and passes to the rumen, or whether it is placed direct into the abomasum and is digested in the intestines. Ruminant digestion is more efficient only when this level of fibre is exceeded.

From a number of reports, Blaxter (196r) has calculated the average effect of increasing the content of dietary fibre on the digestibility of organic matter for several species of animals. In each species, the apparent digestibility of organic matter declined as the fibre content of the diet increased, but the decline was less for ruminants than for non-ruminants. With each $\mathbf{I} \%$ rise in dietary fibre there was a drop in the digestibility of organic matter of $0.86 \%$ for sheep, of $\mathrm{I} \cdot 60 \%$ for pigs and of $\mathrm{I} \cdot 96 \%$ for hens. Because the digestibility of organic matter is correlated with the digestibility of energy, these values can be used to estimate the quantity of digestible energy available to each species for diets containing various quantities of fibre. If the digestive process of a non-ruminant lamb is assumed to resemble that of a pig, an estimate can be made of the level of fibre which must be exceeded before rumen by-pass will result in a lower efficiency of energy utilization.

The fibre content which results in an equal efficiency of energy utilization by the ruminant and non-ruminant lambs will depend upon whether the energy is being used for maintenance or for production, and also upon the proportions of the food subjected to microbial fermentation or digested by host enzymes. For this reason the likely minimum and maximum values for both maintenance and production are shown in Table 5. In calculating the values for the ruminant lamb it is assumed, for one extreme, that no dietary material is digested in the small intestine during maintenance and only $5 \%$ during production, whereas for the other extreme, it is assumed that $20 \%$ of the digestion occurs in the small intestine. For the non-ruminant lamb it is assumed that the minimum amount of energy derived from fermentation in the hindgut can be directly attributed to the digestion of fibre. Since Blaxter (196r) found that each unit increase in dietary fibre resulted in a $1.96 \%$ decrease in digestibility of organic matter in the hen and because microbial digestion in poultry is low (Hobson \& Howard, 1969), it can be assumed that microbial digestion of roughages in animals 
results in the release of about twice as much organic matter as there is fibre digested. If the digestibility of fibre in the hind-gut of lambs is taken to be $30 \%$, the minimum proportion of the diet digested by micro-organisms in the non-ruminant lamb would be about $60 \%$ of the quantity of fibre in the diet. On the other hand, when some starches are given, a greater proportion of the diet may be digested in the hind-gut, and although the maximum amount which may be released in this organ is difficult to assess, it was previously assumed to be about $30 \%$ of the diet.

By making the above assumptions, it can be seen from Table 5 that, if dietary energy is to be used more efficiently in the ruminant lamb, the level of fibre must exceed between 24 and $33 \%$ when energy is used for maintenance, and between 22 and $35 \%$ when energy is used for production. The lower values would probably occur with high-starch diets, whereas the higher values would be more applicable to forage diets.

The crude-fibre component of a food refers to several different substances, including cellulose, lignin, hexans, pectin, pentosans and polyuronides. Some of these substances are more readily digested by micro-organisms than others. For example, in ruminants the digestibility of lignin is generally less than $40 \%$ (Hogan \& Weston, 1969), while the digestibility of cellulose and hemicellulose is about $70 \%$ (Keys et al. 1969). The digestibility of crude fibre is generally much less in non-ruminants, but hemicellulose is digested relatively better than cellulose in non-ruminants than in ruminants (Keys et al. 1969). Thus, the higher the cellulose content of the crude fibre relative to hemicellulose, the greater the advantages of ruminant digestion.

It is apparent that many common foods would be more efficiently used by ruminants if they escaped fermentation in the rumen. However, in practice, there may be some limitations to the theoretical advantage of rumen by-pass. The capacity of the digestive tract of a lamb is considerably less when the rumen and reticulum are not used, and this may restrict the intake of fibrous food by animals in which the rumen is by-passed. There is some evidence suggesting that the concentration of dietary fibre at which food intake is limited by the capacity of the digestive tract is lower in nonruminants than in ruminants.

When ruminants are fed on roughage diets they tend to cease eating when the amount of digesta in the rumen reaches a certain upper limit (Blaxter, Wainman \& Wilson, 196r; Freer \& Campling, r 963). Hence, food intake depends primarily upon the rate of passage of material from the rumen (Ulyatt, Blaxter \& McDonald, I967). In turn, the rate of passage from the rumen of sheep and cattle fed ad lib. depends on the digestibility of the food, which is influenced by its crude-fibre content (Blaxter, I962), and the size of the roughage particles (Balch \& Campling, 1965; Welch, 1967). The voluntary intake of roughage diets increases as digestibility increases and as the particle size decreases. On the other hand, when ruminants are fed on concentrate diets they tend to eat to a constant level of digestible energy intake (Boling, Faltin, Hoekstra \& Hauser, 1967). Preston \& Hembry (1969) have suggested that, when the digestibility of a diet is less than $68 \%$, food intake by ruminants is limited by the rate of passage of material from the rumen, but when the digestibility is above this level food intake is regulated to provide a constant intake of digestible energy. This value 


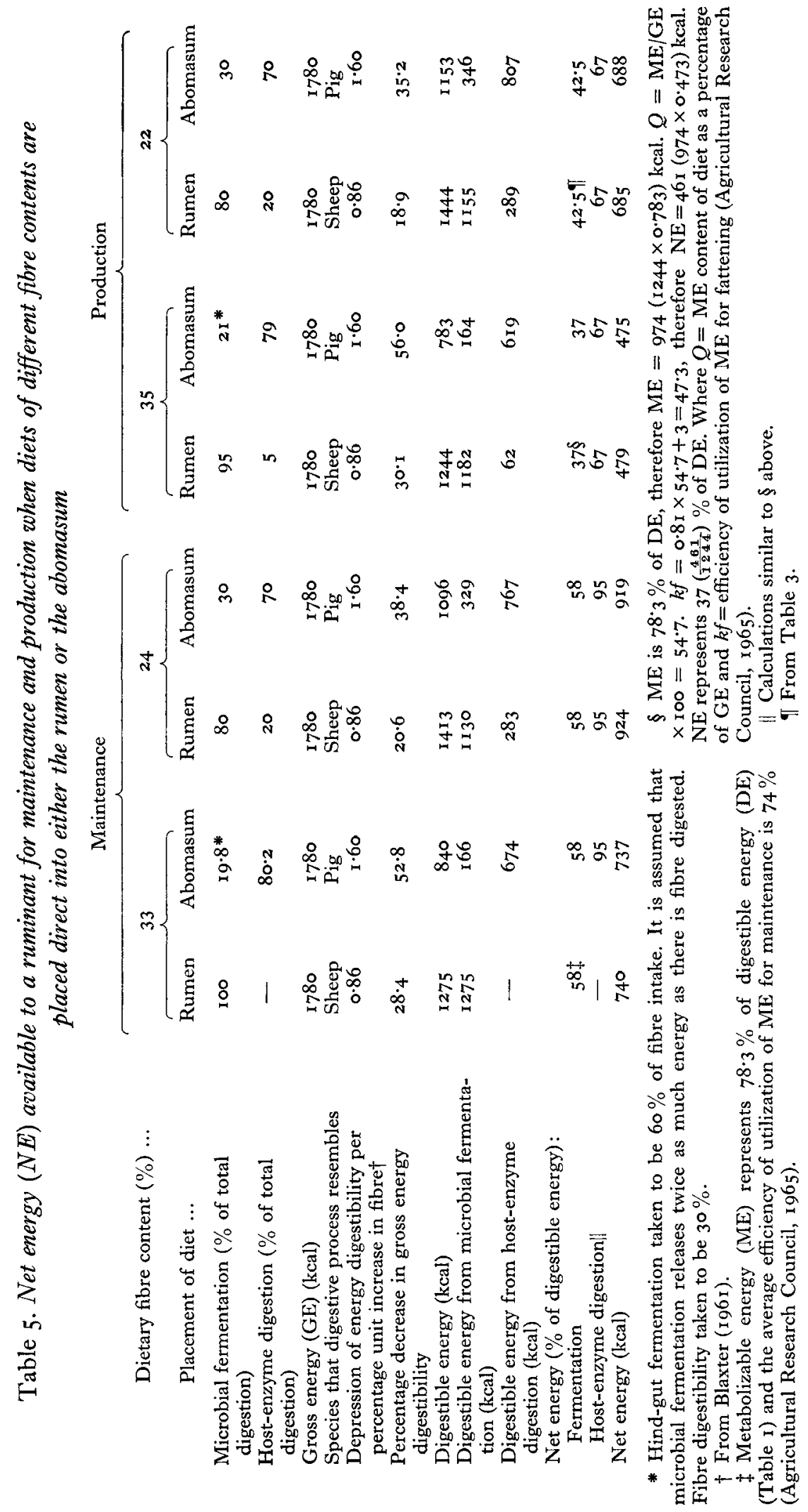


is only an approximation. Andrews, Kay \& Ørskov (I969) have recently suggested that the concentration of dietary fibre above which food intake of lambs is restricted alters with the state of maturity of the animals. Lambs weighing $40 \mathrm{~kg}$, but not lambs weighing $20 \mathrm{~kg}$, could increase their intake of fibrous diets to compensate for the decrease in energy digestibility. If the estimate of Preston \& Hembry (I969) is assumed to be an average value, by using the equation, $D=87.8-0.83 F$, established by Axelsson (cited by Blaxter, 1962) to estimate the apparent digestibility $(D)$ of the organic matter of a diet from the crude-fibre content of the dry matter $(F)$, it can be calculated that when diets contain more than approximately $24 \%$ crude fibre the energy intake of ruminants will be limited.

Non-ruminants also tend to cease eating at a constant level of digestible energy intake. Peterson, Grau \& Peek (1954) formulated a series of diets containing $0-36 \%$ indigestible wood cellulose and found, when the diets were given to chicks, that digestible energy intakes were similar. Likewise, Eriksson (1952) found that the intake of rabbits increased to compensate for increased fibre content in their diets, at least for diets containing up to $19 \%$ crude fibre. Sibbald, Berg \& Bowland (1956) showed that the digestible energy intake of rats consuming a diet which contained $30 \%$ indigestible cellulose was the same as that of other rats consuming more concentrated diets. In contrast to ruminants, it appears that the rate of passage of feed through the digestive tract of non-ruminants is greatly increased by an increase in the fibre content of the diet consumed (Abgarowicz, 1948). However, a level of fibre must eventually be reached at which intake cannot be increased enough to compensate for the decrease in the digestibility of the diet. Cameron (1960) found that the performance of pigs was reduced when the crude-fibre content of the diet was raised to $13 \%$. In contrast, Cole, Duckworth \& Holmes (1967) recorded similar growth rates in pigs given either 13 or $9 \%$ dietary fibre. The ability of pigs to increase food intake when given high-fibre diets is improved by a period of adaptation (Owen \& Ridgman, 1968). Thus, it seems that energy intake is often restricted in non-ruminants at lower levels of dietary fibre than in ruminants.

Another reason why the theoretical advantage of rumen by-pass may not always be important in practice is that, if animals eat to a constant level of energy intake and digestibility does not limit the intake of the ruminant, both the ruminant lamb and the non-ruminant lamb may consume sufficient food to achieve the same maximum level of production. In this situation the ruminant lamb would eat more food and use it less efficiently.

To utilize the theoretical advantage of intestinal digestion in ruminants, methods must be available to prevent the fermentation of food. McDonald (1968) has recently outlined the techniques which have been used to reduce the degradation of dietary protein in the rumen. Some of these procedures can also be used to reduce the loss of dietary energy. These include increasing the rate of passage of material from the rumen, for example, by feeding high levels of sodium chloride (Hemsley, 1967 ), and coating food particles with substances which are stable in the rumen but which disintegrate when they reach the acidic conditions of the abomasum. In addition, two other methods could be used to increase the quantity of dietary material which is 
digested in the small intestine of ruminants: $(a)$ a high level of dietary fat and $(b)$ maintaining or re-establishing the function of the reticular groove.

\section{Dietary fat}

In the rumen, triglycerides are hydrolysed to produce fatty acids and glycerol (Lough \& Garton, 1968). The glycerol is fermented to propionic acid and absorbed from the rumen, while the fatty acids become saturated and pass with other digesta to the abomasum. These acids are eventually absorbed from the intestine and utilized in body processes. They are used more efficiently for both maintenance and fat deposition than are the VFA formed during carbohydrate fermentation (Blaxter, I962).

The most significant energy loss occurring during the digestion of fat in the rumen is the heat evolved in the conversion of glycerol into propionic acid. Although this amounts to $7.5 \%$ of the energy of glycerol, glycerol itself contributes only $5 \%$ of the energy of triglycerides containing $\mathrm{C}_{18}$ fatty acids. Therefore, the heat of fermentation lost during formation of propionic acid accounts for about $0.4 \%$ of the energy of the fat. Moreover, the use of hydrogen atoms during the saturation of fatty acids in the rumen would be expected to reduce the energy lost as methane.

Table 6. Effectiveness of dietary fat in reducing the loss of energy during fermentation in ruminants. A diet containing $10 \%$ fat, $15 \%$ casein and $75 \%$ carbohydrate was given to supply a gross energy intake of $\mathrm{I} 780 \mathrm{kcall} / \mathrm{d}(365 \mathrm{~g}$ diet). The carbohydrate now supplies ${ }_{21} \%$ less energy than in the diet shown in Table $\mathrm{I}$. The values in parentheses represent the gain in energy due to the substitution of fat for carbohydrate

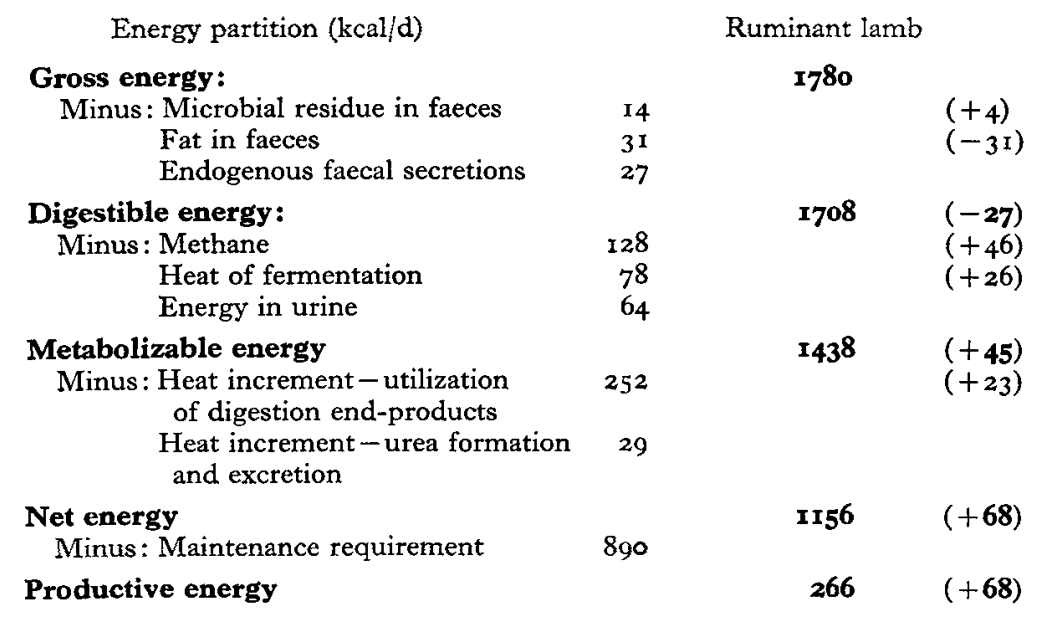

The digestibility of most fat is high, ranging from 90 to $99 \%$ when ingested by non-ruminants (Stokes, 1968). Van De Kamer \& Weijers (196r) found that saturated and long-chain fatty acids are more poorly absorbed in man than unsaturated and short-chain acids. Because the fermentation of fats results in saturation of fatty acids, it could be expected that fats may have a lower digestibility when ingested by ruminants. It has been shown that fat from ruminant adipose tissue, tallow, is less efficiently 
digested in man than vegetable oils (Van De Kamer \& Weijers, I96I) and this could be due to a high degree of saturation. The digestibility of fat by ruminants was estimated to be $90 \%$ for sheep given ${ }^{14} \mathrm{C}$-labelled tripalmitin by injection into the rumen (Heath \& Morris, 1962 ) and $91 \%$ for cattle given $5.6 \%$ animal fat in the diet (Bradley, Jones, Mitchell \& Little, r966)

On these grounds, ruminants should use fat more efficiently than carbohydrate as an energy source. If for the diet considered in this paper, $10 \%$ of the carbohydrate were to be replaced by fat and the digestibility of the fat were $9 \mathrm{I} \%$, then the amount of energy available to the ruminant lamb would be increased by $68 \mathrm{kcal}(285 \mathrm{~kJ})$. This is an increase of only $6 \%$ in net energy but is a $34 \%$ increase in the productive energy available to the ruminant lamb.

Swift, Bratzler, James, Tillman \& Meek (1948) showed that the quantity of dietary energy lost as both heat and methane was reduced when the fat content of a diet for lambs was increased from 3 to $10.5 \%$. Fat has also been efficiently used when added to the diets of fattening steers (Esplin, Hale, Hubbert \& Taylor, 1963) and rearing calves (Johnson, Dolge, Rousseau, Teichman, Eaton, Beall \& Moore, 1956). However, results from other experiments suggest that fat reduced the digestibility of other dietary components, particularly fibre, and its use may be disadvantageous in production (Brooks, Garner, Gehrke, Muhrer \& Pfander, 1954; Grainger, Bell, Stroud \& Baker, I96r; Bradley et al. 1966). Because digestive enzymes in the rumen occur in the aqueous phase, dietary particles coated with fat are more slowly attacked by these enzymes and may pass from the rumen before normal digestion has been completed. The decrease in food digestion can be partly eliminated by the addition of lucerne ash which reduces the coating of food particles by fat (Brooks et al. 1954).

The addition of fat to the diets of ruminants may improve their energy status, but because of its effect on the digestibility of other dietary components the quantity which can be added is limited to about $10 \%$ of the diet. However, the technique developed recently by Scott, Cook, Ferguson \& McDonald (1970) for producing an oil-sodium caseinate complex, which is almost completely resistant to microbial degradation in the rumen, provides a possible means for increasing the quantity of dietary fat well above 10\% without affecting the digestibility of other dietary components.

\section{Reticular groove}

An effective method of reducing or preventing the fermentation of food in the reticulo-rumen is by using the reticular groove; the natural method of rumen by-pass. In young ruminants the suckling of a liquid diet stimulates the closure of the reticular groove and the diet is channelled past the fermentation chambers of the stomach. Raven \& Robinson (196r), Ørskov \& Fraser (1969), Swanson et al. (1969) and Black $(\mathrm{I} 970 a, b)$ have achieved significant increases in the growth of young ruminants when the reticular groove was used to by-pass the rumen.

The reticular groove is also activated by the presence in the mouth of sodium (Riek, 1954), copper (Watson \& Jarrett, 194I), silver and zinc salts (Mönnig \& Quin, 1935) and by the mechanical irritation of the throat (Watson, 1944). However, these methods 
appear to be less effective in stimulating the reticular groove than voluntary suckling (Ørskov \& Benzie, I969).

Evidence suggests that it might also be possible to use the reticular groove as a method of rumen by-pass in adult animals. Watson (1944) reported effective closure of the reticular groove in sheep up to 4 years of age, provided they maintained a desire for milk. Schalk \& Amadon (I928) re-established a preference for milk in an adult cow and observed that when it drank milk the reticular groove closed. However, more research is needed to establish practical methods of stimulating activity of the reticular groove in adult animals.

The author appreciates the financial assistance given during post graduate training by the Australian Wool Board and the Reserve Bank of Australia.

\section{REFERENCES}

Abgarowicz, F. (1948). Untersuchungen über den Einfluss des Ballastes in der Nahrung des Kaninchens. Dissertation: Eidgenossische Technische Hochschule, Zürich. Quoted by Eriksson, S. (1952).

Agricultural Research Council (1965). The Nutrient Requirements of Farm Livestock. No. 2. Ruminants. London: H. M. Stationery Office.

Andrews, R. P., Kay, M. \& Ørskov, E. R. (1969). Anim. Prod. I1, I73.

Armstrong, D. G. (1965). In Physiology of Digestion in the Ruminant p. 272. [R. W. Dougherty, editor]. Washington: Butterworths.

Armstrong, D. G., Blaxter, K. L. \& Graham, N. McC. (1957). Br. F. Nutr. Ir, 392.

Armstrong, D. G., Blaxter, K. L. \& Graham, N. McC. (1960). Proc. Nutr. Soc. r9, xxxi.

Armstrong, D. G., Blaxter, K. L., Graham, N. McC. \& Wainman, F. W. (1958). Br. F. Nutr. I2, I77.

Askevold, F. (1956). Scand. F. clin. Lab. Invest. 8, 87.

Baker, F., Nasr, H., Morrice, F. \& Bruce, J. (r950). F. Path. Bact. 62, 6r 7.

Balch, C. C. \& Campling, R. C. (1965). In Physiology of Digestion in the Ruminant p. 108 [R. W. Dougherty, editor]. Washington: Butterworths.

Bauchop, T. \& Elsden, S. R. (1960). F. gen. Microbiol. 23, 457.

Bender, A. E. \& Miller, D. S. (1953). Biochem. F. 53, vii.

Black, J. L. (1970a). Aust. F. Sci. 32, 332.

Black, J. L. $(1970 b)$. Utilization of protein and energy in growing lambs. PhD Thesis, University of Melbourne.

Blair, H. A., Dern, R. J. \& Bates, P. L. (1947). Am. F. Physiol. 149, 688.

Blaxter, K. L. (I961). Fedn Proc. Fedn Am. Socs exp. Biol. 20, Suppl. 7, p. 268.

Blaxter, K. L. (1962). The Energy Metabolism of Ruminants. London: Hutchinson.

Blaxter, K. L. \& Clapperton, J. L. (1965). Br. F. Nutr. r9, 5 r r.

Blaxter, K. L., Clapperton, J. L. \& Wainman, F. W. (1966). F. agric. Sci., Camb. 67, 67.

Blaxter, K. L. \& Martin, A. K. (1962). Br. F. Nutr. r6, 397.

Blaxter, K. L., Wainman, F. W. \& Wilson, R. S. (I961). Anim. Prod. 3, 5 I.

Boling, J. A., Faltin, E. C., Hoekstra, W. G. \& Hauser, E. R. (1967). F. Anim. Sci. 26, ${ }_{3} 85$.

Bradley, N. W., Jones, B. M. Jr, Mitchell, G. E. Jr \& Little, C. O. (rg66). F. Anim. Sci. 25, 480.

Brooks, C. C., Garner, G. B., Gehrke, C. W., Muhrer, M. E. \& Pfander, W. H. (1954). F. Anim. Sci. $13,758$.

Bruce, J., Goodall, E. D., Kay, R. N. B., Phillipson, A. T. \& Vowles, L. E. (1966). Proc. R. Soc. B $166,46$.

Cameron, C. D. T. (1960). Can. F. Anim. Sci. 40, 126.

Chalmers, M. I., Cuthbertson, D. P. \& Synge, R. L. M. (1954). F. agric. Sci., Camb. 44, 254.

Clary, J. J., Mitchell, G. E. Jr \& Little, C. O. (1967). F. Anim. Sci. 26, 917.

Cole, D. J. A., Duckworth, J. E. \& Holmes, W. (1967). Anim. Prod. 9, I49.

Conrad, H. R., Miles, R. C. \& Butdorf, J. (I967). F. Nutr. 9r, 337.

De Groot, A. P. \& Hoogendoorn, P. (1956). Neth. Milk Dairy $\mathcal{F}$. xr, 290.

Elliott, J. M. \& Loosli, J. K. (1959). Y. Dairy Sci. 42, 843 .

Ellis, N. C., Garner, G. B., Muhrer, M. E. \& Pfander, W. H. (1956). \%. Nutr. 6o, 4r3.

el-Shazly, K. (1952). Biochem. F. 51, 647.

Ely, D. G., Little, C. O., Woolfolk,, P. G. \& Mitchell, G. E. Jr (I967). F. Nutr. gr, 3 I4. 
Eriksson, S. (1952). K. LantbrHögsk. Annlr I9, 7.

Esplin, G., Hale, W. H. Hubbert, F. Jr. \& Taylor, B. (1963). F. Anim. Sci. 22, 695.

Ferguson, K. A., Hemsley, J. A. \& Reis, P. J. (г967). Aust. F. Sci. 30, $2 \times 5$.

Fonnesbeck, P. V. (1969). f. Anim. Sci. 28, 624.

Freer, M. \& Campling, R. C. (1963). Br. F. Nutr. 17, 79.

Graham, N. McC. (1967). Aust. F. agric. Res. 18, I27.

Grainger, R. B., Bell, M. C., Stroud, J. W. \& Baker, F. H. (r96r). F. Anim. Sci. 20, 319.

Heath, T. J. \& Morris, B. (1962). Q. $\mathscr{~} l$ exp. Physiol. 47, I57.

Hedin, P. A. (1962). F. Nutr. 77, 471.

Hedin, P. A. \& Adachi, R. A. (1962). F. Nutr. 77, 229.

Hemsley, J. A. (1967). Aust. F. exp. Biol. med. Sci. 45, P-39.

Hobson, P. N. \& Howard, B. H. (1969). In Handbuch Der Tiernernährung Vol. I. Allgemeine Grundlagen p. 207 [W. Lenkeit, K. Breirem and E. Crasemann, editors]. Hamburg and Berlin: Verlag P. Parey.

Hogan, J. P. \& Weston, R. H. (1967a). Aust. F. agric. Res. 18, 803.

Hogan, J. P. \& Weston, R. H. (1967b). Aust. F. agric. Res. 18, 973.

Hogan, J. P. \& Weston, R. H. (1968). Proc. Aust. Soc. Anim. Prod. 7, 364.

Hogan, J. P. \& Weston, R. H. (1969). Aust. Y. agric. Res. 20, 347.

Hoogenraad, N. J., Hird, F. J. R., White, R. G. \& Leng, R. A. (1970). Br. F. Nutr. 24 , 129.

Huber, J. T. (1969). F. Dairy Sci. 52, 1303.

Huber, J. T., Jacobson, N. L., Allen, R. S. \& Hartman, P. A. (I961). F. Dairy Sci. 44, I494.

Huber, J. T., Natrajan, S. \& Polan, C. E. (1967). F. Dairy Sci. 50, 116 r.

Huber, J. T., Rifkin, R. J. \& Keith, J. M. (1964). F. Dairy Sci. 47, 789.

Hungate, R. E. (1965). In Physiology of Digestion in the Ruminant, p. 3 I I [R. W. Dougherty, editor]. Washington: Butterworths.

Hungate, R. E. (1966). The Rumen and its Microbes. London and New York: Academic Press.

Hutchinson, K. J. (1958). Aust. F. agric. Res. 9, 508 .

Jagusch, K. T. (1968). Utilization of energy by the milk-fed lamb, with special reference to the composition of the gain in weight. $\mathrm{PhD}$ Thesis, University of Sydney.

Johnson, B. C., Hamilton, T. S., Robinson, W. B. \& Garey, J. C. (1944). F. Anim. Sci. 3, 287.

Johnson, D. Jr, Dolge, K. L., Rousseau, J. E. Jr Teichman, R., Eaton, H. D., Beall, G. \& Moore L. A. (1956). F. Dairy Sci. 39, 268.

Keys, J. E., Van Soest, P. J. \& Young, E. P. (1969). F. Anim. Sci. 29, 11.

Kirk, E. (1949). Gastroenterology 12, 782.

Krebs, H. A. (1964). In Mammalian Protein Metabolism Vol. I, p. 125 [H. N. Munro and J. B. Allison, editors]. London and New York: Academic Press.

Leathem, J. H. (I 964). In Mammalian Protein Metabolism Vol. 1, p. 343 [H. N. Munro and J. B. Allison, editors]. London and New York: Academic Press.

Loesche, W. J. (1968). Proc. Soc. exp. Biol. Med. 129, 380.

Lough, A. K. \& Garton, G. A. (1968). In Comparative Nutrition of Wild Animals p. I63 [M. A. Crawford, editor]. London and New York: Academic Press.

McDonald, I. W. (1968). Aust. vet. F. 44, 145.

McDonald, I. W. \& Hall, R. J. (x957). Biochem. F. 67, 400.

McNaught, M. L., Owen, E. C., Henry, K. M. \& Kon, S. K. (1954). Biochem. F. 56, I 51.

Marshall, R. A. (1949). Br. F. Nutr. 3, I.

Marston, H. R. (1948). Biochem. F. 42, 564 .

Martin, A. K. (1969). Br. F. Nutr. 23, 389 .

Martin, A. K. \& Blaxter, K. L. (1965). In Energy Metabolism p. 83 [K. L. Blaxter, editor]. London and New York: Academic Press.

Meyer, J. H., Kromann, R. \& Garrett, W. N. (1965). In Physiology of Digestion in the Ruminant p. 262. [R. W. Dougherty, editor]. Washington: Butterworths.

Mönnig, N. O. \& Quin, J. I. (1935). Onderstepoort F. vet. Sci. Anim. Ind. 5, 485.

Munro, H. N. (195I). Physiol. Rev. 31, 449.

Nehring, K., Hoffmann, L. Schiemann, R. \& Jentsch, W. (1963). Arch. Tierernähr. 13, 193.

Norton, B. W. (I968). The nutrition of the milk-fed lamb: nitrogen retention during growth. PhD Thesis, University of Sydney.

Ørskov, E. R. \& Benzie, D. (I969). Br. F. Nutr. 23, 4I 5.

Ørskov, E. R. \& Fraser, C. (I 968). Proc. Nutr. Soc. 27, 37 A.

Ørskov, E. R. \& Fraser, C. (r969). Anim. Prod. rr, 28r.

Ørskov, E. R., Fraser, C. \& Kay, R. N. B. (1969). Br. F. Nutr. $23,217$.

Owen, J. B. \& Ridgman, W. J. (1968). Anim. Prod. 10, 85.

Paladines, O. L., Reid, J. T., Van Niekerk, B. D. H. \& Bensadoun, A. (r964). F. Anim. Sci. $23,528$.

Peterson, D. W., Grau, C. R. \& Peek, N. F. (1954). F. Nutr. 52, 24 I.

Platt, B. S. \& Miller, D. S. (1959). Proc. Nutr. Soc. 18, vii. 
Preston, R. L. \& Hembry, F. G. (1969). Pfizer Ann. Res. Conf. 17, 74.

Putnam, P. A. \& Davis, R. E. (1965). F. Anim. Sci. 24, 826.

Raven, A. M. \& Robinson, K. L. (1961). Nature, Lond. 192, 1256.

Reed, I. M., Moir, R. J. \& Underwood, E. J. (I949). Aust. F. scient. Res. B 2, 304.

Reid, R. L. (1968). In A Practical Guide to the Study of the Productivity of Large Herbivores p. I9o [F. B. Golley and H. K. Buechner, editors]. Oxford: Blackwell.

Reid, R. L., Hogan, J. P. \& Briggs, P. K. (1957). Aust. F. agric. Res. 8, $69 \mathrm{I}$.

Reis, P. J. (1969). Aust. F. biol. Sci. 22, 745.

Reis, P. J. \& Schinckel, P. G. (1961). Aust. F. agric. Res. 12, 335.

Reis, P. J. \& Schinckel, P. G. (1963). Aust. F. biol. Sci. 16, 218.

Reis, P. J. \& Schinckel, P. G. (1964). Aust. F. biol. Sci. 17, 532.

Riek, R. F. (1954). Aust. vet. F. 30, 29.

Schalk, A. F. \& Amadon, R. S. (I928). Bull. N. Dak. agric. Exp. Stn no. 216.

Scott, T. W., Cook, L. J., Ferguson, K. A. \& McDonald, I. W. (1970). Aust. F. Sci. 32, 29 I.

Sibbald, I. R., Berg, R. T. \& Bowland, J. P. (1956). F. Nutr. 59, 385.

Smith, R. H. (I969). F. Dairy Res. 36, 313 .

Snyderman, S. E. (1967). In Urea as a Protein Supplement p. 441 [M. H. Briggs, editor]. London: Pergamon Press.

Stokes, G. B. (1968). The nutritive value of fat in the diet of the milk-fed lamb. MSc Thesis, University of Sydney.

Swanson, E. W., Thigpen, J. E., Huskey, J. \& Hazlewood, B. P. (1969). F. Dairy Sci. 52, 228.

Swift, R. W., Bratzler, J. W., James, W. H., Tillman, A. D. \& Meek, D. C. (1948). F. Anim. Sci. 7, 475.

Topps, J. H., Kay, R. N. B. \& Goodall, E. D. (I968). Br. Y. Nutr. 22, 26 I.

Tucker, R. E., Mitchell, G. E. Jr \& Little, C. O. (I968). F. Anim. Sci. 27, 824.

Ulyatt, M. J., Blaxter, K. L. \& McDonald, I. (1967). Anim. Prod. 9, 463.

Van De Kamer, J. H. \& Weijers, H. A. (1961). Fedn Proc. Fedn Am. Socs exp. Biol. 20, Suppl. 7, p. 335 .

Vidal, H. M., Hogue, D. E., Elliott, J. M. \& Walker, E. F. Jr. (1969). F. Anim. Sci. 29, 62.

Walker, D. J. (1965). In Physiology of Digestion in the Ruminant p. 296 [R. W. Dougherty, editor]. Washington: Butterworths.

Walker, D. M. (1959). F. agric. Sci, Camb. 53, 374.

Walker, D. M. \& Cook, L. J. (1967). Br. F. Nutr. 21, 237.

Walker, D. M. \& Faichney, G. J. (1964a). Br. F. Nutr. 18, 187.

Walker, D. M. \& Faichney, G. J. (1964b). Br. F. Nutr. 18, 209.

Warner, R. L., Mitchell, G. E. Jr \& Little, C. O. (I968). F. Anim. Sci. 27, 1773.

Watson, R. H. (1944). Bull. Coun. scient. ind. Res., Melb. 180, I.

Watson, R. H. \& Jarrett, I. G. (194I). Aust. vet. F. I7, I37.

Welch, J. G. (1967). Y. Anim. Sci. 26, 849.

Wright, P. L., Grainger, R. B. \& Marco, G. J. (1966). F. Nutr. 89, 24 I. 